\title{
Nocardia iowensis sp. nov., an organism rich in biocatalytically important enzymes and nitric oxide synthase
}

Correspondence John P. N. Rosazza john-rosazza@uiowa.edu

\author{
Andrew S. Lamm, ${ }^{1}$ Arshdeep Khare, ${ }^{1}$ Patricia Conville, ${ }^{2}$ Peter C. K. Lau, ${ }^{3}$ \\ Hélène Bergeron ${ }^{3}$ and John P. N. Rosazza ${ }^{1}$
}

${ }^{1}$ Center for Biocatalysis and Bioprocessing, 2501 Crosspark Road, Suite C100 Oakdale Research Park, University of lowa, lowa City, IA 52242-5000, USA
${ }^{2}$ Microbiology Service, Department of Laboratory Medicine, Warren G. Magnuson Clinical Center, National Institutes of Health, US Department of Health and Human Services, Bethesda, MD 20892-1508, USA
${ }^{3}$ Biotechnology Research Institute, National Research Council Canada, 6100 Royalmount Ave., Montreal, Quebec H4P 2R2, Canada

\begin{abstract}
Nocardia strain NRRL 5646, isolated from a garden soil sample in Osceola, lowa, USA, was initially of interest as an antibiotic producer. It contained biocatalytically important enzymes and represented the first described nitric oxide synthase enzyme system in bacteria. The present polyphasic taxonomic study was undertaken to differentiate strain NRRL $5646^{\top}$ from related species of the genus Nocardia. Chemotaxonomic analyses included determinations of the fatty acid methyl ester profile $\left(\mathrm{C}_{16: 1} \omega 6 c / \mathrm{C}_{16: 1} \omega 7 c, \mathrm{C}_{16: 0}, \mathrm{C}_{18: 1} \omega 9 c\right.$ and $\mathrm{C}_{18: 0}$ 10-methyl as major components), quinone [cyclo $\mathrm{MK}-8\left(\mathrm{H}_{4}\right)$ as the major component], polar lipid

(diphosphatidylglycerol, phosphatidylethanolamine, phosphatidylinositol and phosphatidylinositol mannoside as major components) and mycolic acid. These results supported its placement within the genus Nocardia. Biochemical testing and 16S rRNA, 65-kDa heat-shock protein ( $h s p 65)$ and preprotein translocase ( $\sec A 1$ ) gene sequence analyses differentiated strain NRRL $5646^{\top}$ from recognized Nocardia species. Previous studies have demonstrated that other genetic sequences (carboxylic acid reductase, Nocardia phosphopantetheinyl transferase and GTP cyclohydrolase I) from strain NRRL $5646^{\top}$ can also be used to substantiate its uniqueness. The level of $16 S$ rRNA gene sequence similarity between strain NRRL $5646^{\top}$ and the type strains of Nocardia tenerifensis and Nocardia brasiliensis was $98.8 \%$. However, strain NRRL $5646^{\top}$ could be clearly distinguished from these Nocardia species based on DNA-DNA hybridization data.

Consequently, strain NRRL $5646^{\top}$ is considered to represent a novel species of the genus Nocardia, for which the name Nocardia iowensis sp. nov. is proposed. The type strain is NRRL $5646^{\top}\left(=\right.$ UI $122540^{\top}=$ NRRL B $-24671^{\top}=$ DSM $\left.45197^{\top}\right)$.
\end{abstract}

Strain NRRL $5646^{\mathrm{T}}$ was initially identified as an antibioticproducing bacterium isolated from a garden soil sample in Osceola, Iowa, USA (Hlavka \& Bitha, 1977; Martin et al., 1977). This strain showed an extraordinary diversity of biotransforming enzymes and the first bacterial nitric oxide synthase (NOS) system with possible physiological importance, making its identification to the species level important. Strain NRRL $5646^{\mathrm{T}}$ converts many natural and synthetic organic compounds into valuable products,

Abbreviation: NOS, nitric oxide synthase.

The GenBank/EMBL/DDBJ accession numbers for the 16S rRNA, secA1 and hsp65 gene sequences of strain NRRL $5646^{\top}$ are D0.925490, EU650382 and EU650383, respectively. including flavonoids (Herath et al., 2006; Maatooq \& Rosazza, 2005), vanillic acid (Dhar et al., 2007) and 4vinylphenol (Lee \& Rosazza, 2002). A novel ATP/NADPHdependent carboxylic acid reductase was isolated from strain NRRL 5646 ${ }^{\mathrm{T}}$ (Li \& Rosazza, 1997) and subsequently cloned (car; GenBank accession number AY495697; He et al., 2004a). The reduction system required a phosphopantetheinyl transferase ( $n p t$, GenBank accession number DQ904035; Venkitasubramanian et al., 2007). Strain NRRL $5646^{\mathrm{T}}$ contains the first NOS system characterized in prokaryotes (Chen \& Rosazza, 1995). As part of the NOS system, strain NRRL $5646^{\mathrm{T}}$ contains guanylate cyclase for cyclic GMP synthesis (Son \& Rosazza, 2000), and GTP cyclohydrolase I ( $g c h$; GenBank accession number 
AY128670; He et al., 2004b) for tetrahydrobiopterin biosynthesis.

The present polyphasic taxonomic study was used to identify strain NRRL $5646^{\mathrm{T}}$ to the species level. Phenotypic, biochemical, chemotaxonomic (fatty acid methyl esters, quinones, polar lipids, mycolic acids) and genotypic [16S rRNA, $65-\mathrm{kDa}$ heat-shock protein (hsp65) and preprotein translocase (secA1) gene sequence analyses, DNA-DNA hybridization] characteristics were used to show that strain NRRL $5646^{\mathrm{T}}$ represents a novel species of the genus Nocardia.

Strain NRRL $5646^{\mathrm{T}}$ was grown and maintained on sporulating agar slants (Li \& Rosazza, 1997) at room temperature for 5 days and was maintained at $4{ }^{\circ} \mathrm{C}$. Strain NRRL $5646^{\mathrm{T}}$ was grown in shaken flask cultures at $29^{\circ} \mathrm{C}$ to provide cell pellets for analysis as described by Li \& Rosazza (1997). The strain initially grew as a whitish mycelium on sporulating agar at $29{ }^{\circ} \mathrm{C}$ and after several days showed whitish aerial hyphae. Smears were prepared from the growth on sporulating agar and were Gram stained according to Gerhardt et al. (1994). Smears were also stained via the modified Ziehl-Neelsen method of Gordon (1967) to determine the degree of acid-fastness. Cells of strain NRRL $5646^{\mathrm{T}}$ stained as Gram-positive rods with branching characteristic of Nocardia species. The acidfastness of strain NRRL $5646^{\mathrm{T}}$ was confirmed by using modified Kinyoun acid-fast staining (Brown-Elliott et al., 2006). For scanning electron microscopy analysis at the Central Electron Microscopy Research Facility at the University of Iowa, an agar block containing substrate and aerial mycelium was fixed with $25 \%$ glutaraldehyde and subsequently stained with $1 \%$ osmium tetroxide. The sample was rinsed with $0.1 \mathrm{M}$ cacodylate buffer, then water and then progressively dehydrated with increasing concentrations of ethanol. The sample was critical-point dried, mounted on stubs and sputter coated, and scanning electron micrographs were taken with a Hitachi S-4800 scanning electron microscope. Micrographs revealed branching aerial hyphae.

The cultural, morphological and phenotypic properties of strain NRRL $5646^{\mathrm{T}}$ were originally described by Martin et al. (1977) and Hlavka \& Bitha (1977). Additional biochemical tests were done by using Nocardia ID QUAD plates (BD Microbiology Systems), bile aesculin agar and urea agar slants (BD Microbiology Systems). Hydrolysis of hypoxanthine and uric acid was determined as described by Isik et al. (1999). Duplicate plates containing the relevant substrates were inoculated from a glycerol stock and incubated at $29{ }^{\circ} \mathrm{C}$ for $2-4$ weeks. Results of the physiological characterization are given in the species description below.

Fatty acid and mycolic acid profiles of strain NRRL $5646^{\mathrm{T}}$ were determined by Microbial ID, Inc., Newark, Delaware, USA (http://www.microbialid.com), by using the Sherlock Microbial Identification System software (MIDI Inc.) following standard protocols (Miller, 1982; Sasser, 1990;
Butler et al., 1986). Bacterial samples were grown at $29{ }^{\circ} \mathrm{C}$ on freshly prepared yeast-malt extract agar (Difco) prior to analysis. The major fatty acids of strain NRRL $5646^{\mathrm{T}}$ were $\mathrm{C}_{16: 0}\left(28.2 \%\right.$ of the total), $\mathrm{C}_{18: 1} \omega 9 c(27.9 \%)$ and $\mathrm{C}_{18: 0}$ 10-methyl (18.4\%). A mixture of $\mathrm{C}_{16: 1} \omega 6 c$ and $\mathrm{C}_{16: 1} \omega 7 c$ fatty acids was also detected as a significant component $(19.2 \%)$. This profile most closely matches those of members of the genus Nocardia. Table 1 provides a comparison of the fatty acid profiles of strain NRRL $5646^{\mathrm{T}}$ and the type strains of closely related Nocardia species.

Mycolic acid analysis also confirmed strain NRRL $5646^{\mathrm{T}}$ as a member of the genus Nocardia. MIS (Microbial Indentification System) library comparisons gave low similarity indices of $0.346,0.313$ and 0.262 for strain

Table 1. Fatty acid methyl ester profiles of strain NRRL $5646^{\top}$ and the type strains of related Nocardia species

Strains: 1, NRRL $5646^{\mathrm{T}}$ (N. iowensis sp. nov.); 2, N. tenerifensis DSM $44704^{\mathrm{T}}$; 3, N. transvalensis DSM $43405^{\mathrm{T}}$; 4, N. brasiliensis DSM $43758^{\mathrm{T}}$; 5, N. farcinica DSM $43665^{\mathrm{T}}$; 6. N. beijingensis DSM $44636^{\mathrm{T}}$. Values are percentages of the total fatty acids. For unsaturated fatty acids, the position of the double bond is located by counting from the methyl $(\omega)$ end of the carbon chain; cis and trans isomers are indicated by the suffixes $c$ and $t$, respectively. Data for reference strains were taken from Kämpfer et al. (2004). TSBA, Tuberculostearic acid. -, Not detected.

\begin{tabular}{|lcccccc|}
\hline Fatty acid & $\mathbf{1}$ & $\mathbf{2}$ & $\mathbf{3}$ & $\mathbf{4}$ & $\mathbf{5}$ & $\mathbf{6}$ \\
\hline $\mathrm{C}_{10: 0}$ & 0.2 & 0.3 & 0.1 & 0.1 & 0.1 & 0.02 \\
$\mathrm{C}_{11: 0}$ & - & - & - & - & 0.02 & - \\
$\mathrm{C}_{12: 0}$ & - & - & 0.5 & 0.2 & 0.3 & - \\
$\mathrm{C}_{14: 0}$ & 0.5 & 0.7 & 1.8 & 1.4 & 1.6 & 1.1 \\
$\mathrm{C}_{15: 0}$ & - & 0.4 & 0.5 & 1.2 & - & 2.0 \\
$\mathrm{C}_{15: 1} \omega 5 c$ & 0.2 & - & - & - & - & 0.2 \\
$\mathrm{C}_{16: 1} \omega 9 c$ & 0.2 & 0.3 & 0.9 & 0.3 & 0.2 & 0.2 \\
$\mathrm{C}_{16: 1} \omega 6 c$ and & 19.2 & - & - & - & - & - \\
$\mathrm{C}_{16: 1} \omega 7 c$ & & & & & & \\
$\mathrm{C}_{16: 0}$ & 28.2 & 44.5 & 39.7 & 40.0 & 37.7 & 37.9 \\
$\mathrm{C}_{17: 1} \omega 9 c$ & - & - & - & - & 1.3 & - \\
$\mathrm{C}_{17: 1} \omega 8 c$ & 2.1 & - & 0.6 & 0.6 & - & 1.4 \\
$\mathrm{C}_{17: 1} \omega 5 c$ & - & 0.8 & - & - & - & - \\
$\mathrm{C}_{17: 0}$ & 1.4 & 0.3 & 0.7 & 1.0 & 0.6 & 2.8 \\
$\mathrm{C}_{18: 3} \omega 6,9,12 c$ & - & 0.3 & - & - & - & - \\
$\mathrm{C}_{17: 0} 10-\mathrm{methyl}$ & 0.6 & - & 0.3 & - & 0.3 & 0.5 \\
$\mathrm{C}_{18: 1} \omega 7 c$ & - & - & 0.8 & - & - & - \\
$\mathrm{C}_{18: 1} \omega 9 c$ & 27.9 & 15.0 & 22.9 & 24.0 & 24.8 & 18.6 \\
$\mathrm{C}_{18: 0}$ & 0.6 & 4.3 & 4.6 & 7.9 & 13.6 & 6.5 \\
$\mathrm{C}_{18: 0} 10-$ methyl & 18.4 & 20.3 & 15.4 & 12.9 & 10.8 & 9.9 \\
$(\mathrm{TBSA})$ & & & & & & \\
$\mathrm{C}_{19: 0}$ & - & - & - & - & - & 0.7 \\
$\mathrm{C}_{19: 1} \omega 9 c$ and & 0.2 & 0.5 & 0.4 & 0.6 & - & 0.9 \\
$\mathrm{C}_{19: 1} \omega 11 c$ & & & & & & \\
$\mathrm{C}_{20: 0}$ & - & - & - & - & 0.6 & - \\
$\mathrm{C}_{20: 4} \omega 6,9,12,15 c$ & - & - & - & - & - & 0.4 \\
$\mathrm{C}_{20: 2} \omega 6,9 c$ & - & 0.5 & - & - & - & - \\
$\mathrm{C}_{20: 1} \omega 9 c$ & 0.5 & - & 1.3 & - & 1.4 & 0.3 \\
& & & & & & \\
\hline
\end{tabular}


NRRL $5646^{\mathrm{T}}$ versus the type strains of Nocardia carnea, Nocardia brasiliensis and Nocardia asteroides, respectively. Thus, although strain NRRL $5646^{\mathrm{T}}$ was not present in the Microbial ID, Inc. databases, it has a mycolic acid composition similar to those of recognized members of the genus Nocardia.

Polar lipids and menaquinone analyses of strain NRRL $5646^{\mathrm{T}}$ (performed by the DSMZ, Braunschweig, Germany; http://www.dsmz.de), important classification tools for the identification of members of the genus Nocardia (Kämpfer et al., 2004), revealed the presence of diphosphatidylglycerol, phosphatidylethanolamine, phosphatidylinositol and phosphatidylinositol mannoside as major polar lipids, and cyclo MK-8 $\left(\mathrm{H}_{4}\right)$ as the major quinone. These data also supported the affiliation of strain NRRL $5646^{\mathrm{T}}$ to the genus Nocardia.
Near-full-length 16S rRNA gene sequences are considered to provide reliable criteria for identification of members of the genus Nocardia (Brown-Elliott et al., 2006; Roth et al., 2003; Wauters et al., 2005). Moreover, a variable region that exists within the first $500 \mathrm{bp}$ of the gene is considered to be the basis for a reliable method for species differentiation among members of the genus (Conville et al., 2000). The nearly full-length $16 \mathrm{~S}$ rRNA gene sequence of strain NRRL $5646^{\mathrm{T}}$ was determined by using eubacteria primers $27 \mathrm{f}$ and 1492R (Lane, 1991). A 1.4-kb fragment of the 16S rRNA gene from strain NRRL $5646^{\mathrm{T}}$ was amplified (Lee et al., 2007). Analysis of this sequence via the BLAST program (http://www.ncbi.nlm.nih.gov/blast/ Blast.cgi; Altschul et al., 1997) showed that it shared 98.8\% similarity to Nocardia tenerifensis DSM $44704^{\mathrm{T}}$ and $98.8 \%$ to $N$. brasiliensis DSM $43758^{\mathrm{T}}$ [along with several other

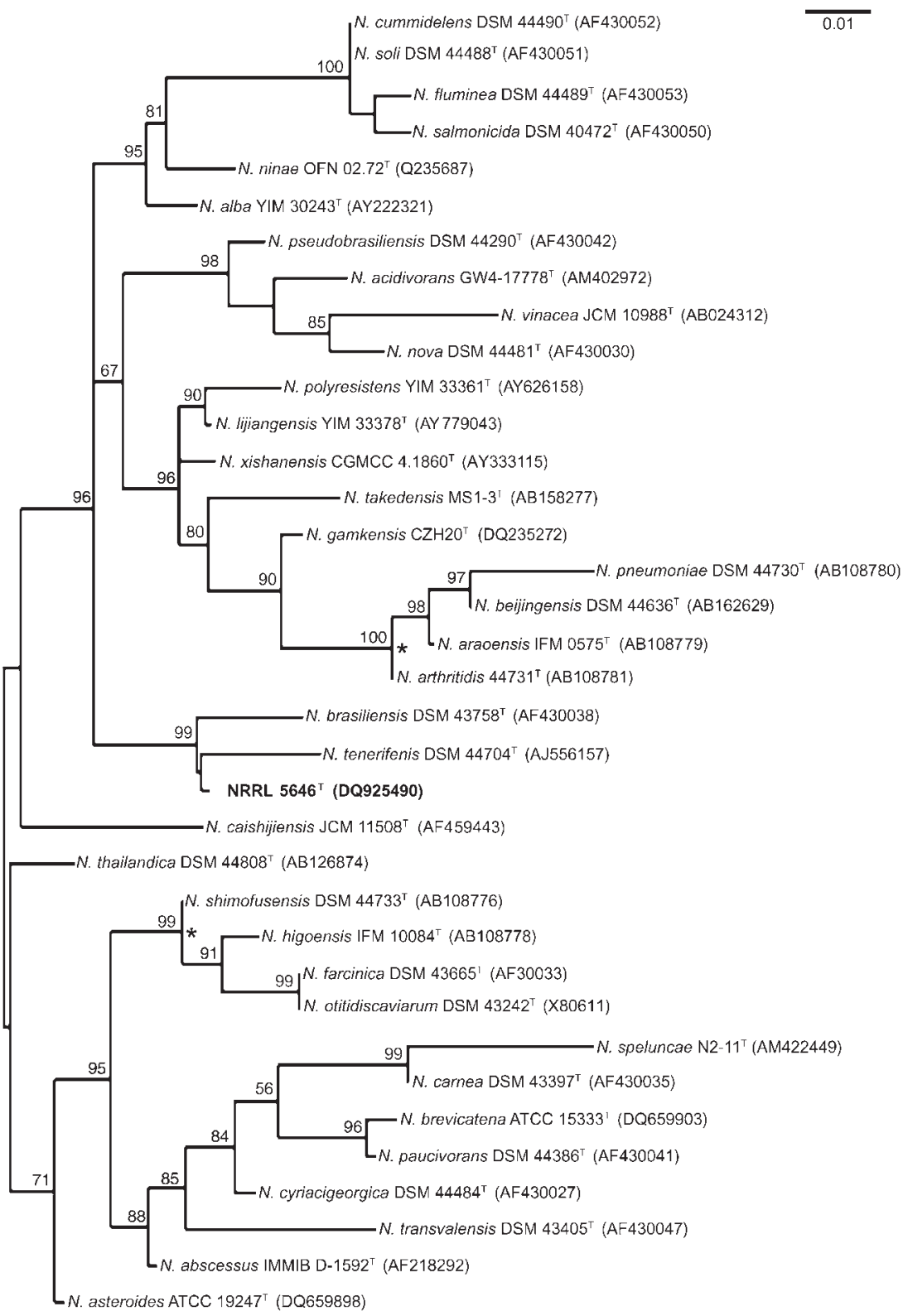

Fig. 1. Unrooted neighbour-joining tree (Saitou \& Nei, 1987), based on nearly complete $16 \mathrm{~S}$ rRNA gene sequences, showing the position of strain NRRL $5646^{\top}$ among representatives of closely related Nocardia species. Phylogenetic data were recovered by using the maximum-likelihood (Felsenstein, 1981) and maximum-parsimony (Kluge \& Farris, 1969) tree-making algorithms, respectively. Numbers at nodes indicate levels of bootstrap support based on a neighbour-joining analysis of 1000 resampled datasets; only values $>50 \%$ are given. Asterisks indicate branches that were also found in trees constructed based on hsp65 and secAl gene sequences (see Figs 2 and 3). Bar, 0.01 changes per nucleotide position. 
N. brasiliensis strains (GenBank accession numbers Z36935, X80608, AY245543, DQ659902 and X80591)]. This confirmed the designation of strain NRRL $5646^{\mathrm{T}}$ to the genus Nocardia but not to any recognized species as at least $99.2 \% 16 \mathrm{~S}$ rRNA gene sequence similarity is required for this level of classification (Conville et al., 2000). The $16 \mathrm{~S}$ rRNA gene sequence of strain NRRL $5646^{\mathrm{T}}$ was aligned with corresponding nucleotide sequences of the type strains of recognized Nocardia species, retrieved from the GenBank/EMBL/DDBJ databases, by using CLUSTAL_X software (Thompson et al., 1997). Phylogenetic trees were inferred by using the least-squares (Fitch \& Margoliash, 1967), maximum-likelihood (Felsenstein, 1981), maximum-parsimony (Kluge \& Farris, 1969) and neighbourjoining (Saitou \& Nei, 1987) algorithms from the PHYLIP suite of programs (Felsenstein, 1993). Evolutionary distance matrices were generated as described by Kimura (1980). The resultant unrooted tree topologies were evaluated by bootstrap analysis (Felsenstein, 1985) of the neighbour-joining method based on 1000 resamplings, by using the SEQBOOT and CONSENSE options within the PHYLIP package. Strain NRRL $5646^{\mathrm{T}}$ formed a distinct phyletic lineage among other species of aerobic actinomycetes (Fig. 1). Within one important variable region of the $16 \mathrm{~S}$ rRNA gene sequence, strain NRRL $5646^{\mathrm{T}}$ (146TTCCAGT-152) differed significantly from that of $N$. tenerifensis DSM $44704^{\mathrm{T}} \quad$ (172-TCATGTC-178) and showed one base difference from $N$. brasiliensis DSM $43758^{\mathrm{T}}$ (149-TTTCAGT-155). (Nucleotide position numbers above refer to the original GenBank 16S rRNA gene sequences whereas comparisons were made based on CLUSTAL_X alignment.) This signature sequence also distinguished strain NRRL $5646^{\mathrm{T}}$ from the type strains of N. asteroides, Nocardia farcinica, Nocardia nova, Nocardia otitidiscaviarum, Nocardia pseudobrasiliensis and Nocardia transvalensis (Conville et al., 2006). On this basis, strain NRRL $5646^{\mathrm{T}}$ probably represents a novel Nocardia species. Strain NRRL $5646^{\mathrm{T}}$ differed from all other recognized

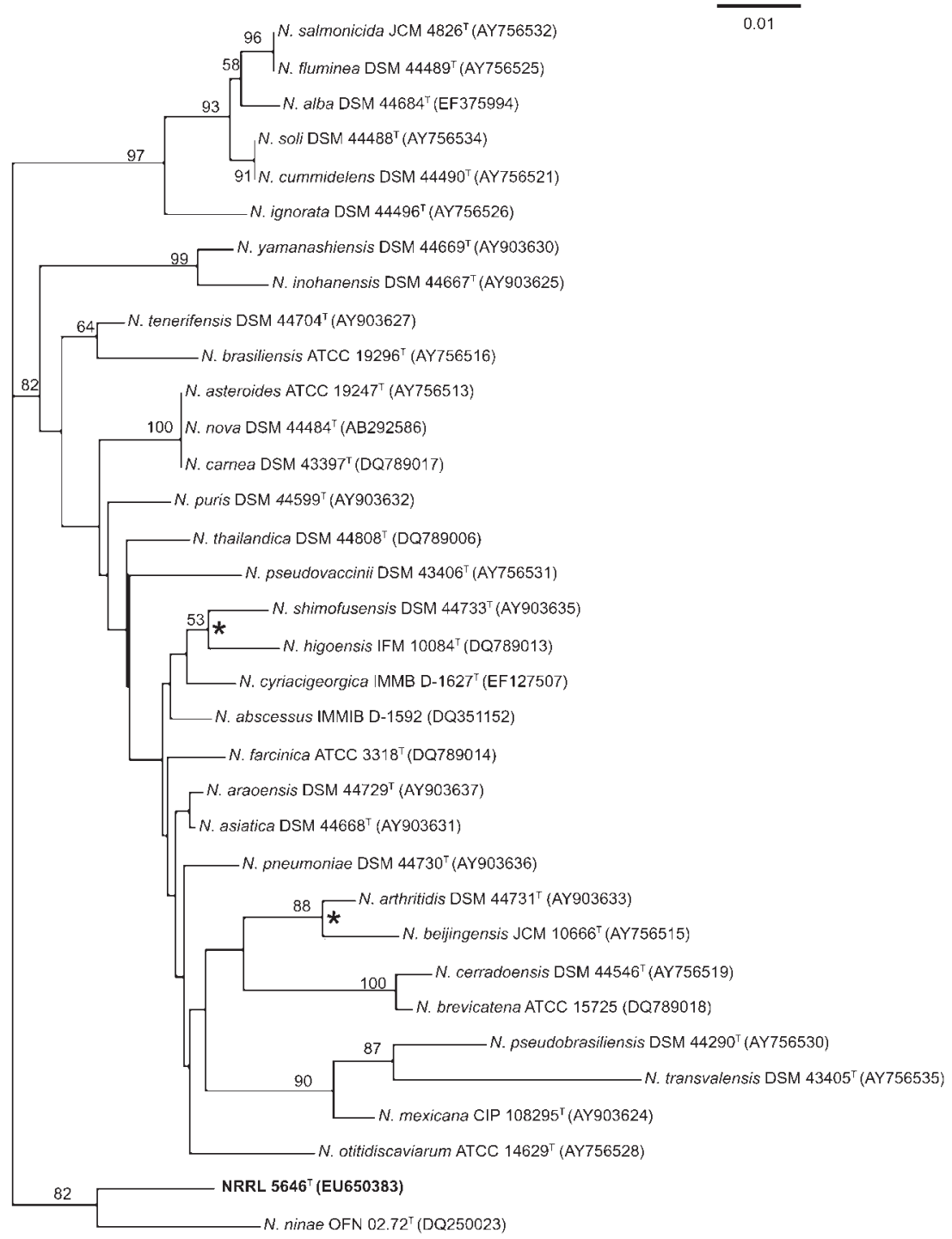

Fig. 2. Unrooted neighbour-joining tree (Saitou \& Nei, 1987), based on complete hsp65 gene sequences, showing the position of strain NRRL $5646^{\top}$ among representatives of closely related Nocardia species. Phylogenetic data were recovered by using the maximum-likelihood (Felsenstein, 1981) and maximum-parsimony (Kluge \& Farris, 1969) tree-making algorithms, respectively. Numbers at nodes indicate levels of bootstrap support based on a neighbour-joining analysis of 1000 resampled datasets; only values $>50 \%$ are given. Asterisks indicate branches that were also found in trees constructed based on 16S rRNA and secAl gene sequences (see Figs 1 and 3 ). Bar, 0.01 changes per nucleotide position. 
species of the genus with regard to this variable region of the $16 \mathrm{~S}$ rRNA gene.

The use of hsp65 gene sequences (but not hsp65 PCRrestriction enzyme pattern analysis) containing sufficient polymorphism was found to be as reliable as 16S rRNA gene sequence analysis for comprehensive Nocardia species identification (Rodriguez-Nava et al., 2006). Additionally, $\sec A 1$ gene sequences have been shown to be useful in this regard (Conville et al., 2006). As a result, public sequence repositories such as GenBank have a growing number of both hsp65 and secA1 gene sequences.

The hsp65 and secA1 genes of strain NRRL $5646^{\mathrm{T}}$ were amplified and sequenced according to Conville et al. (2000, 2006), respectively. Levels of $h s p 65$ and secAl gene sequence analysis were again determined by performing BLAST searches. Evaluation of hsp65 gene sequence multiple alignment data placed the novel strain in the genus Nocardia with closest matches to the type strains of Nocardia ninae (95.9\% similarity), N. tenerifensis (95.7\%), Nocardia arthritidis (94.9\%) and N. brasiliensis (94.6\%). The neighbour-joining phylogenetic tree based on hsp65 gene sequences is shown in Fig. 2. The secA1 gene sequence alignment data also placed strain NRRL $5646^{\mathrm{T}}$ within the genus Nocardia with closest matches to the type strains of Nocardia pneumoniae (95.5\% similarity), N. brasiliensis (95.3\%), Nocardia beijingensis (95.3\%) and N. asteroides (95.3\%). The neighbour-joining phylogenetic tree based on secA1 gene sequences is shown in Fig. 3.

DNA-DNA hybridization experiments (performed by the DSMZ) between strain NRRL $5646^{\mathrm{T}}$ and itself, $N$. tenerifensis DSM $44704^{\mathrm{T}}$ and $N$. brasiliensis DSM $43758^{\mathrm{T}}$ revealed levels of relatedness of 92.1 (94.9), 5.4 (7.4) and $19.9 \%(15.8 \%)$, respectively (values in parentheses are the

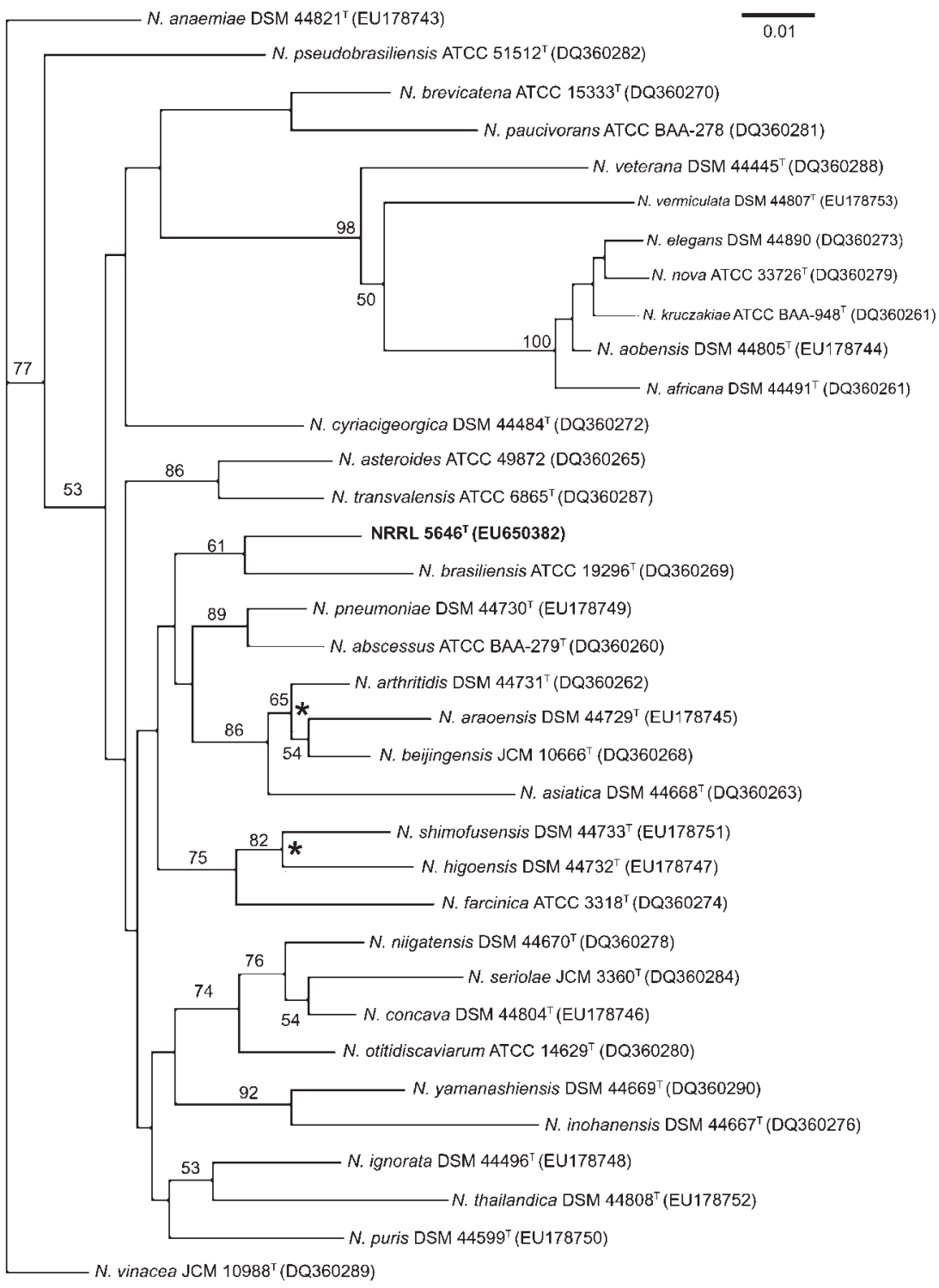

Fig. 3. Unrooted neighbour-joining tree (Saitou \& Nei, 1987), based on complete $\sec A 1$ gene sequences, showing the position of strain NRRL $5646^{\top}$ among representatives of closely related Nocardia species. Phylogenetic data were recovered by using the maximum-likelihood (Felsenstein, 1981) and maximum-parsimony (Kluge \& Farris, 1969) tree-making algorithms, respectively. Numbers at nodes indicate levels of bootstrap support based on a neighbour-joining analysis of 1000 resampled datasets; only values $>50 \%$ are given. Asterisks indicate branches that were also found in trees constructed based on 16S rRNA and hsp65 gene sequences (see Figs 1 and 2). Bar, 0.01 changes per nucleotide position. 
results of duplicate measurements). Based on the recommended threshold value of $70 \%$ DNA-DNA relatedness for species delineation (Wayne et al., 1987), strain NRRL $5646^{\mathrm{T}}$ represents a species distinct from $N$. tenerifensis and N. brasiliensis.

In addition, BLAST searches and analysis of car, $n p t$ and $g c h$ gene sequences of strain NRRL $5646^{\mathrm{T}}$ revealed closest matches to $N$. farcinica IFM 10152, with maximum similarity values of 74,84 and $81 \%$, respectively. However, N. farcinica IFM 10152 is the only Nocardia taxon for which the entire genome sequence has been established (Ishikawa et al., 2004).

Based on the above physiological, biochemical and chemotaxonomic analyses, strain NRRL $5646^{\mathrm{T}}$ is considered to represent a novel species of the genus Nocardia, for which the name Nocardia iowensis sp. nov. is proposed.

\section{Description of Nocardia iowensis sp. nov.}

Nocardia iowensis (i.o.wen'sis. N.L. fem. adj. iowensis after the state of Iowa, from where the type strain was isolated).

Initial growth on sporulating agar at $29^{\circ} \mathrm{C}$ is as a whitish mycelium followed by whitish aerial hyphae after incubation for 5 days. Cells are Gram-positive branching rods that are acid-fast. Moderate growth occurs on yeast extract, asparagine glucose, Benedict's, Bennett's potato starch and Weinstein agars; light growth occurs on Hickey and Tresner's, tomato paste and oatmeal agars; and only trace growth occurs on inorganic salts-starch, Kustner's oatflake, Czapek's solution and rice agars. No growth occurs with Lrhamnose, adonitol, L-arabinose, melibiose or D-xylose. Predominant fatty acids are $\mathrm{C}_{16: 0}, \mathrm{C}_{18: 1} \omega 9 c$ and $\mathrm{C}_{18: 0} 10$ methyl, plus a mixture of $\mathrm{C}_{16: 1} \omega 6 c$ and $\mathrm{C}_{16: 1} \omega 7 c$. The major menaquinone is cyclo $\mathrm{MK}-8\left(\mathrm{H}_{4}\right)$. Polar lipids present are diphosphatidylglycerol, phosphatidylethanolamine, phosphatidylinositol and phosphatidylinositol mannoside. No soluble pigments are produced; no liquefaction of gelatin. Nitrates are reduced to nitrites in 7 days. Can tolerate $>4$ but $<7 \% \mathrm{NaCl}$ in yeast extract agar. Catalasepositive. Hydrolyses aesculin, urea and starch. Degrades xanthine, tyrosine, hypoxanthine and uric acid but not casein. Optimum temperature for growth is $29^{\circ} \mathrm{C}$. Utilization of carbon sources and additional phenotypic properties are given in Table 2.

The type strain, NRRL $5646^{\mathrm{T}}\left(=\mathrm{UI} 122540^{\mathrm{T}}=\right.$ NRRL B$24671^{\mathrm{T}}=$ DSM $45197^{\mathrm{T}}$ ), was isolated from soil in Osceola, Iowa, USA.

\section{Acknowledgements}

We acknowledge the assistance of Claude Pujol and Jean Ross at the University of Iowa. This work was supported by the Iowa Biotechnology Byproducts Consortium, through the Cooperative State Research, Education and Extension Service, US Department of Agriculture, under Agreement nos 2002-34188-12035 and 200434188-15067. Any opinions, findings, conclusions or recommendations expressed in this publication are those of the authors and do not
Table 2. Differential physiological characteristics of strain NRRL $5646^{\top}$ and the type strains of Nocardia species grouped in the same cluster on the basis of 16S rRNA gene sequence analysis

Strains: 1, NRRL $5646^{\mathrm{T}}$ (N. iowensis sp. nov.); 2, N. tenerifensis DSM $44704^{\mathrm{T}} ; 3$, N. brasiliensis DSM $43758^{\mathrm{T}} ; 4$, N. beijingensis DSM $44636^{\mathrm{T}}$; 5, N. takedensis DSM 44801 ${ }^{\mathrm{T}}$. +, Positive; (+), weakly positive; -, negative; ND, not determined. Data for reference strains were taken from Kämpfer et al. (2004), Wang et al. (2001) and Yamamura et al. (2005). Data for growth on carbon sources for strain NRRL $5646^{\mathrm{T}}$ were taken from Martin et al. (1977) and Hlavka \& Bitha (1977).

\begin{tabular}{|lccccc|}
\hline Characteristic & $\mathbf{1}$ & $\mathbf{2}$ & $\mathbf{3}$ & $\mathbf{4}$ & $\mathbf{5}$ \\
\hline Aesculin hydrolysis & + & + & + & + & - \\
Decomposition of: & & & & & \\
$\quad$ Casein & - & + & + & - & - \\
Tyrosine & + & + & + & - & - \\
Xanthine & + & - & - & + & - \\
Hypoxanthine & + & + & + & - & - \\
Uric acid & + & $\mathrm{ND}$ & - & - & + \\
Growth on sole carbon sources & & & & & \\
$i$-Inositol & + & + & + & - & $\mathrm{ND}$ \\
D-Mannitol & - & + & $(+)$ & $(+)$ & - \\
Trehalose & + & + & + & - & - \\
D-Fructose & $(+)$ & - & - & - & - \\
DL-Lactic acid & - & - & - & - & $\mathrm{ND}$ \\
D-Glucose & + & + & + & + & + \\
Maltose & $(+)$ & - & - & - & $\mathrm{ND}$ \\
Sucrose & - & - & - & - & + \\
Salicin & + & - & - & - & $\mathrm{ND}$ \\
\hline
\end{tabular}

necessarily reflect the views of the US Department of Agriculture. In addition, this research was supported in part by the Intramural Research Program of the NIH Warren G. Magnuson Clinical Center. The views expressed herein are those of the authors and should not be construed as those of the US Department of Health and Human Services.

\section{References}

Altschul, S. F., Madden, T. L., Schäffer, A. A., Zhang, J., Zhang, Z., Miller, W. \& Lipman, D. J. (1997). Gapped BLAST and PSI-BLAST: a new generation of protein database search programs. Nucleic Acids Res 25, 3389-3402.

Brown-Elliott, B. A., Brown, J. M., Conville, P. S. \& Wallace, R. J., Jr (2006). Clinical and laboratory features of the Nocardia spp. based on current molecular taxonomy. Clin Microbiol Rev 19, 259-282.

Butler, W. R., Ahearn, D. G. \& Kilburn, J. O. (1986). High-performance liquid chromatography of mycolic acids as a tool in the identification of Corynebacterium, Nocardia, Rhodococcus, and Mycobacterium species. J Clin Microbiol 23, 182-185.

Chen, Y. \& Rosazza, J. P. N. (1995). Purification and characterization of nitric oxide synthase $\left(\mathrm{NOS}_{\mathrm{Noc}}\right)$ from a Nocardia species. J Bacteriol 177, 5122-5128.

Conville, P. S., Fischer, S. H., Cartwright, C. P. \& Witebsky, F. G. (2000). Identification of Nocardia species by restriction endonuclease analysis of an amplified portion of the $16 \mathrm{~S}$ rRNA gene. J Clin Microbiol 38, 158-164. 
Conville, P. S., Zelazny, A. M. \& Witebsky, F. G. (2006). Analysis of secAl gene sequences for identification of Nocardia species. J Clin Microbiol 44, 2760-2766.

Dhar, A., Lee, K.-S., Dhar, K. \& Rosazza, J. P. N. (2007). Nocardia sp. vanillic acid decarboxylase. Enzyme Microb Technol 41, 271-277.

Felsenstein, J. (1981). Evolutionary trees from DNA sequences: a maximum likelihood approach. J Mol Evol 17, 368-376.

Felsenstein, J. (1985). Confidence limits on phylogenies: an approach using the bootstrap. Evolution 39, 783-791.

Felsenstein, J. (1993). PHYLIP (phylogeny inference package), version 3.6. Distributed by the author. Department of Genome Sciences, University of Washington, Seattle, USA.

Fitch, W. M. \& Margoliash, E. (1967). Construction of phylogenetic trees: a method based on mutation distances as estimated from cytochrome c sequences is of general applicability. Science 155, 279-284.

Gerhardt, P., Murray, R. G. E., Wood, W. A. \& Krieg, N. R. (1994). Methods for General and Molecular Bacteriology. Washington, DC: American Society for Microbiology.

Gordon, R. E. (1967). The taxonomy of soil bacteria. In The Ecology of Soil Bacteria, pp. 293-321. Edited by T. R. G. Gray \& D. Parkinson. Liverpool: Liverpool University Press.

He, A., Li, T., Daniels, L., Fotheringham, I. \& Rosazza, J. P. N. (2004a). Nocardia sp. carboxylic acid reductase: cloning, expression and purification of a new oxidoreductase family. Appl Environ Microbiol 70, 1874-1881.

He, A., Simpson, D. R., Daniels, L. \& Rosazza, J. P. N. (2004b). Cloning, expression, purification and characterization of Nocardia sp. GTP cyclohydrolase I. Protein Expr Purif 35, 171-180.

Herath, W., Mikell, J. R., Hale, A. L., Ferreira, D. \& Khan, A. I. (2006). Microbial metabolism. Part 6. Metabolites of 3- and 7-hydroxyflavones. Chem Pharm Bull (Tokyo) 54, 320-324.

Hlavka, J. J. \& Bitha, P. (1977). Alkylated derivatives of antibiotic BM123\%. United States Patent 4,048,431.

Ishikawa, J., Yamashita, A., Mikami, Y., Hoshino, Y., Kurita, H., Hotta, K., Shiba, T. \& Hattori, M. (2004). The complete genomic sequence of Nocardia farcinica IFM 10152. Proc Natl Acad Sci U S A 101, 14925-14930.

Isik, K., Chun, J., Hah, Y. C. \& Goodfellow, M. (1999). Nocardia salmonicida nom. rev., a fish pathogen. Int J Syst Bacteriol 49, 833-837.

Kämpfer, P., Buczolits, S., Jäckel, U., Grün-Wollny, I. \& Busse, H.-J. (2004). Nocardia tenerifensis sp. nov. Int J Syst Evol Microbiol 54, 381383.

Kimura, M. (1980). A simple method for estimating evolutionary rates of base substitutions through comparative studies of nucleotide sequences. J Mol Evol 16, 111-120.

Kluge, A. G. \& Farris, F. S. (1969). Quantitative phyletics and the evolution of anurans. Syst Zool 18, 1-32.

Lane, D. J. (1991). 16S/23S rRNA sequencing. In Nucleic Acid Techniques in Bacterial Systematics, pp. 115-175. Edited by E. Stackebrandt \& M. Goodfellow. Chichester: Wiley.

Lee, K.-S. \& Rosazza, J. P. N. (2002). Biocatalytic oxidation of 4vinylphenol by Nocardia. Can J Chem 80, 582-588.
Lee, S., Bergeron, H., Lau, P. C. K. \& Rosazza, J. P. N. (2007). Thiols in a nitric oxide synthase-containing Nocardia sp. strain NRRL 5646. Appl Environ Microbiol 73, 3095-3097.

Li, T. \& Rosazza, J. P. N. (1997). Purification, characterization and properties of an aryl aldehyde oxidoreductase from Nocardia sp. strain NRRL 5646. J Bacteriol 179, 3482-3487.

Maatooq, G. T. \& Rosazza, J. P. N. (2005). Metabolism of daidzein by Nocardia species NRRL 5646 and Mortierella isabellina ATCC 38063. Phytochemistry 66, 1007-1011.

Martin, J. H. E. J., Tresner, H. D. \& Porter, J. N. (1977). Antibiotic BM123 and production thereof. United States Patent 4,007,167.

Miller, L. T. (1982). Single derivatization method for routine analysis of bacterial whole-cell fatty acid methyl esters, including hydroxy acids. J Clin Microbiol 16, 584-586.

Rodriguez-Nava, V. A., Couble, A., Devulder, G., Flandrois, J.-P., Boiron, P. \& Laurent, F. (2006). Use of PCR-restriction enzyme pattern analysis and sequencing database for $h s p 65$ gene-based identification of Nocardia species. J Clin Microbiol 44, 536-546.

Roth, A., Andrees, S., Kroppenstedt, R. M., Harmsen, D. \& Mauch, H. (2003). Phylogeny of the genus Nocardia based on reassessed $16 \mathrm{~S}$ rRNA gene sequences reveals underspeciation and division of strains classified as Nocardia asteroides into three established species and two unnamed taxons. J Clin Microbiol 41, 851-856.

Saitou, N. \& Nei, M. (1987). The neighbor-joining method: a new method for reconstructing phylogenetic trees. Mol Biol Evol 4, 406425.

Sasser, M. (1990). Identification of bacteria by gas chromatography of cellular fatty acids, MIDI Technical Note 101. Newark, DE: MIDI Inc.

Son, J.-K. \& Rosazza, J. P. N. (2000). Cyclic GMP and biopteridine biosynthesis in Nocardia. J Bacteriol 182, 3644-3648.

Thompson, J. D., Gibson, T. J., Plewniak, F., Jeanmougin, F. \& Higgins, D. G. (1997). The CLUSTAL_X windows interface: flexible strategies for multiple sequence alignment aided by quality analysis tools. Nucleic Acids Res 25, 4876-4882.

Venkitasubramanian, P., Daniels, L. \& Rosazza, J. P. N. (2007). Reduction of carboxylic acids by Nocardia aldehyde oxido-reductase requires a phosphopantetheinylated enzyme. J Biol Chem 282, 478485.

Wang, L., Zhang, Y., Lu, Z., Shi, Y., Liu, Z., Maldonado, L. \& Goodfellow, M. (2001). Nocardia beijingensis sp. nov., a novel isolate from soil. Int J Syst Evol Microbiol 51, 1783-1788.

Wauters, G., Avesani, V., Charlier, J., Janssens, M., Vaneechoutte, M. \& Delmee, M. (2005). Distribution of Nocardia species in clinical samples and their routine rapid identification in the laboratory. J Clin Microbiol 43, 2624-2628.

Wayne, L. G., Brenner, D. J., Colwell, R. R., Grimont, P. A. D., Kandler, O., Krichevsky, M. I., Moore, L. H., Moore, W. E. C., Murray, R. G. E. \& other authors (1987). International Committee on Systematic Bacteriology. Report of the ad hoc committee on reconciliation of approaches to bacterial systematics. Int J Syst Bacteriol 37, 463-464.

Yamamura, H., Hayakawa, M., Nagakawa, Y., Tamura, T., Kohono, T., Komatsu, F. \& Imura, Y. (2005). Nocardia takedensis sp. nov., isolated from moat sediment and scumming activated sludge. Int J Syst Evol Microbiol 55, 433-436. 